\title{
Kajian Teknis Budidaya Pakan Alami Daphnia sp di Unit Hatchery dan Mina B Agribisnis Kota Bogor Provinsi Jawa Barat
}

\author{
[Technical Study of Natural Feed Cultivation of Daphnia sp in the Hatchery \\ Unit and Mina B Agribusiness, Bogor City, West Java Province]
}

\section{O.D. Soebhakti Hasan, Adang Kasmawijaya}

Politeknik Ahli Usaha Perikanan Jakarta

\begin{abstract}
Abstrak
Jumlah produksi Daphnia sp yang rendah dari hasil kegiatan budidaya sehingga menyebabkan minimnya ketersediaan pakan alami Daphnia sp menjadi suatu permasalahan yang perlu memerlukan kajian. Kajian teknis budidaya pakan alami Daphnia sp di Mina B Agribisnis dan Hatchery Unit Praktek Lapang Komunikasi dan Penyuluhan Kota Bogor merupakan kegiatan dalam penggalian data dan informasi tentang metode budidaya Daphnia sp yang digunakan di pembudidaya serta penerapan pakan alami Daphnia pada kegiatan budidaya ikan. Tujuan penelitian ini yaitu pengumpulan data dan informasi tentang metode budidaya Daphnia sp serta mengetahui akar permasalahan dalam kinerja produksi budidaya Daphnia sp yang dilaksanakan di pembudidaya wilayah Kota Bogor. Metode pengumpulan data menggunakan observasi dan pengukuran langsung. Alat yang digunakan untuk pengambilan data berupa borang data isian laju populasi, biomass, dan parameter kualitas air untuk budidaya Daphnia sp. Lokasi pengambilan data terbagi dalam 2 lokasi yang terbagi 3 unit budidaya yaitu kelompok Mina B Agribisnis (Unit A), kolam outdoor hatchery (Unit B), dan kolam indoor hatchery (Unit C). Analisis yang digunakan berupa analisis deskriftif dan fishbone analysis. Berdasarkan hasil kajian,indikator kinerja produksi dilihat dari jumlah populasi Daphnia sp dan biomass yang dihasilkan pada tiap lokasi unit usaha antara lain jumlah populasi unit A sebanyak $1.436 \mathrm{ind} / \mathrm{L}$ dengan biomass $1.539 \mathrm{mg} / \mathrm{L}$, unit $B$ sebanyak $317 \mathrm{ind} / \mathrm{L}$ dengan biomass 337 $\mathrm{mg} / \mathrm{L}$ dan unit C $390 \mathrm{ind} / \mathrm{L}$ dengan biomass $416 \mathrm{mg} / \mathrm{L}$.
\end{abstract}

Kata kunci : Pakan alami; Daphnia sp; Laju Populasi; Biomass.

\section{Abstract}

Zooplankton natural feed is an alternative type of feed used at The initial period of cultivation. The consideration of its high protein content. The technical study of Daphnia sp natural feed cultivation at Mina B Agribusiness and Hatchery Field Communication and Extension Practice Unit in Bogor City is an activity in extracting data and information about Daphnia sp cultivation methods used in cultivators and the application of Daphnia natural food in fish farming activities. The purpose of this research is to collect data and information about the cultivation method of Daphnia sp and to know the root cause of the problem in the production performance of Daphnia sp cultivation which is carried out in cultivators in the city of Bogor. The data collection method uses direct observation and measurement. The tools used for data collection were forms in the form of data on population rate, biomass, and water quality parameters for the cultivation of Daphnia sp. The location of data collection is divided into 2 locations divided into 3 cultivation units, namely the Mina B Agribusiness group (Unit A), the outdoor Hatchery pool (Unit B) and the indoor hatchery pool (Unit C)... The analysis used was descriptive analysis and fishbone analysis. Based on the results of the study, it was found that production performance indicators were seen from the total population of Daphnia sp and the biomass produced at each location of the business unit, including the population of unit $A$ as much as 1,436 ind / $L$ with biomass $1,539 \mathrm{mg} / \mathrm{L}$, unit $B$ as much as $317 \mathrm{ind} / \mathrm{L}$ with biomass 337. $\mathrm{mg} / \mathrm{L}$ and unit C $390 \mathrm{ind} /$ $\mathrm{L}$ with biomass $416 \mathrm{mg} / \mathrm{L}$. 
Kajian Teknis Budidaya Pakan Alami Daphnia

sp di Unit Hatchery dan Mina B Agribisnis Kota Bogor Provinsi Jawa Barat

Keywords : Natural feed; Daphnia sp; Population Rate; Biomass.

\section{Penulis Korespondensi}

O.D. Soebhakti Hasan | otiedylan@gmail.com

\section{PENDAHULUAN}

Faktor penentu keberhasilan dalam budidaya perikanan salah satunya yaitu pakan. Pemilihan jenis pakan yang digunakan mempertimbangan baik dari segi kandungan protein, ketersediaan jumlah pakan, serta biaya yang dikeluarkan. Pakan alami jenis zooplankton merupakan salah satu alternatif jenis pakan yang digunakan pada awal masa pemeliharaan.

Daphnia sp adalah mikroorganisme jenis krustacea (ordo Cladocera, famili Daphniidae) yang hidup di perairan tawar (Pangkey 2009). Ada terdapat banyak jenis/spesies dari Daphniidae dengan tingkat penyebarannya yang luas. Dari semua spesies yang ada, Daphnia dan Moina yang paling dikenal dan banyak digunakan sebagai pakan alami

Daphnia sp merupakan krustacea sangat kecil dan memiliki tubuh yang terlindungi oleh semacam cangkang transparan (karapas transparan) yang terbuat dari bahan polisakarida yang disebut kitin (Surtikanti, Juansah, and Frisda 2017) dan hidup tersebar secara merata di badan perairan (El-Feky \&
Abo-Taleb, 2020). Kandungan protein Daphnia sp mencapai $47,7 \%$ dengan tingkat kalori sebesar 333,7 cal (El Feky \& Abo Taleb, 2020). Selain itu Daphnia sp mempunyai kandungan enzim pencernaan yang berfungsi sebagai ekso enzim pada pencernaan larva ikan seperti enzim proteinase, peptidase, amilase, lipase dan selulase (Pangkey 2009).

Menurut (Ebert 2005; SisonMangus, Mushegian, and Ebert 2015), Daphnia bereproduksi secara seksual dan aseksual dalam arti Daphnia betina menghasilkan 2 jenis sel telur yaitu diploid dan haploid (yang memerlukan fertilisasi). Pada sebagian besar perairan, populasi Daphnia didominasi oleh Daphnia betina yang bereproduksi secara aseksual (sel diploid). Reproduksi secara aseksual dilakukan dengan cara parthenogenesis yaitu reproduksi tanpa adanya fertilisasi. Menurut (Pangkey, 2009), kondisi parthenogenesis terjadi pada kondisi melimpahnya sumber makanan, kandungan oksigen terlarut yang tinggi, temperatur yang optimal serta kepadatan populasi yang rendah (populasi permanen). Pada kondisi 
sebaliknya maka akan terjadi reproduksi secara seksual dan menghasilkan resting eggs (populasi berselang) pada kantung telur (ephippium/resting eggs pouch) yaitu lapisan ekstra yang melindungi telur didalamnya pada tahapan hibernasi dari kondisi lingkungan yang keras hingga kondisi yang memungkinkan untuk melanjutkan siklus hidupnya. Pembuahan ini terjadi pada kantung telur dan dilakukan saat molting dan pengendapan telur ke dalam ephippium

Daphnia sp. termasuk zooplankton yang non selektif filter feeder yang kebiasaan makannya berupa berbagai macam bakteri, alga, detritus, dan bahan organik terlarut. Alga hijau merupakan makanan terbaik untuk Daphnia sp. Daphnia biasanya mengonsumsi partikel nutrisi dengan ukuran sekitar $1 \mu \mathrm{m}$ hingga $50 \mu \mathrm{m}$, meskipun partikel dengan diameter hingga 70 $\mu \mathrm{m}$ dapat ditemukan dalam isi usus individu besar. Dinamika penyerapan makanan oleh Daphnia dipengaruhi oleh tingkat konsentrasi makanan tertentu (food concentration), tingkat serapan makanan dalam air (feeding rate), dan jumlah air yang disaring per satuan waktu (filtering rate) (Ebert, 2005).

Dalam beberapa penelitian selain pakan alami, dalam kegiatan budidaya pakan alami Daphnia sp sering diberikan nutrisi tambahan yang berasal dari produk limbah pertanian dan industri, serta kotoran hewan seperti dedak dari beberapa komoditas hasil pertanian seperti jagung, padi, gandum, kedelai dan kotoran hewan (Akbar, Hamdani, and Buwono 2017; Herawati et al. 2018; Izzah, Suminto, and Herawati 2014) yang dihaluskan terlebih dahulu hingga mencapai ukuran $60 \mu \mathrm{m}$ (EI Feky dan Abo Taleb, 2020)

Penggunaan Daphnia $s p$ biasanya digunakan sebagai sumber pakan pada fase awal pemeliharaan larva ikan air tawar dan beberapa jenis ikan hias (Pangkey H, 2009). Ketersediaan pakan alami Daphnia sp saat ini dipenuhi sebagian besar dari tangkapan alam. Budidaya Daphnia sp masih belum banyak dikembangkan secara komersil dan hanya untuk penggunaan sendiri. Jumlah produksi pakan alami Daphnia sp dari hasil kegiatan budidaya masih rendah yaitu jumlah produksi masih kurang dari 10\% dari jumlah produksi yang seharusnya.

Berdasarkan hal tersebut diatas, maka tujuan dari kajian ini yaitu untuk memperoleh data dan informasi terkait teknologi budidaya Daphnia sp serta mengetahui akar permasalahan yang dihadapi dalam kegiatan budidaya Daphnia sp..

\section{BAHAN DAN METODE}

Kajian ini dilakukan melalui kegiatan pengamatan dipelaku 
utama kegiatan budidaya Daphnia sp

di dua lokasi yaitu Kelompok Mina B

Agribisnis sebanyak 1 unit (Unit A) dengan jumlah kolam 4 buah

berbentuk kolam bulat dengan

diamater rata-rata $2,84 \mathrm{~m}$ dan

Hatchery Unit Praktek Lapang

Komunikasi dan Penyuluhan

(UPLKP) sebanyak 2 unit yaitu kolam

Tabel 1. Data kondisi dan penerapan teknologi yang diambil di setiap lokasi. petak (unit B) sebanyak 7 buah dengan ukuran $1,97 \times 0,90 \mathrm{~m}$ dan kolam bulat (unit $\mathrm{C}$ ) sebanyak 7 buah dengan diamater rata-rata $1,9 \mathrm{~m}$. Data penggunaan teknologi yang diambil untuk ketiga unit tersebut tertera pada tabel 1 .

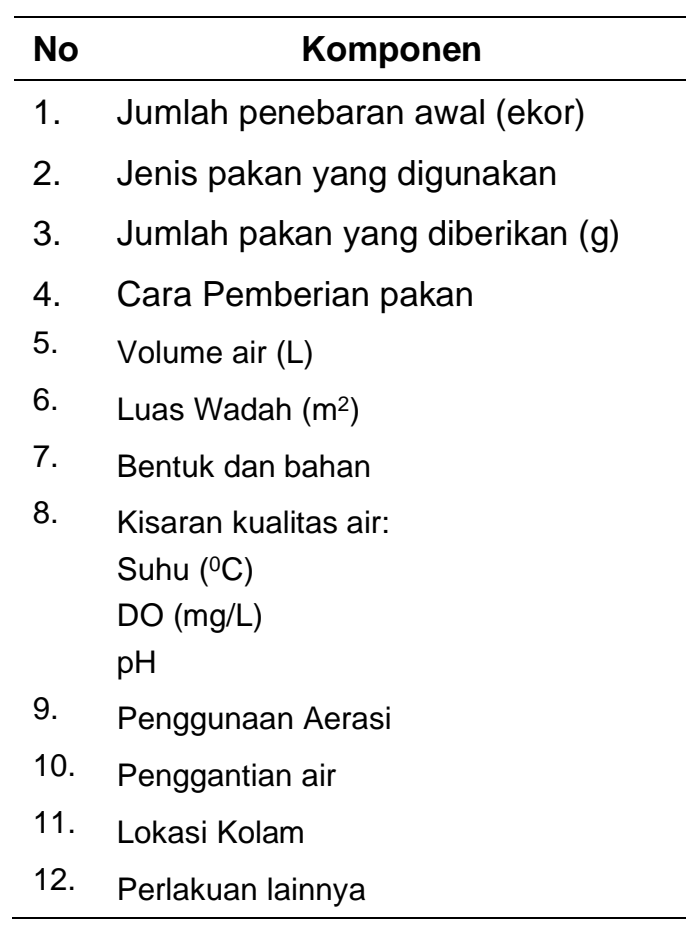

dengan pengadukan wadah

Data yang diambil antara lain:

a) Jumlah populasi Daphnia $s p$ Dalam menghitung jumlah populasi dilakukan dengan cara pengambilan sampel dari wadah pemeliharaan mengunakan metode volumetrik. Pengambilan sampel dilakukan sebanyak 3 (tiga) kali. Adapun pengambilan sampel diawali pemeliharaan terlebih dahulu secara merata kemudian menggunakan wadah ukur $1000 \mathrm{ml}$ dan breaker glass $100 \mathrm{ml}$. Jumlah populasi Daphnia sp dihitung menggunakan rumus menurut (Rahayu \& Piranti, 2009) sebagai berikut:

$$
a=b \times \frac{p}{q}
$$

Keterangan:

$\mathrm{a}=$ Jumlah individu Daphnia sp. pada media kultur (ind/L) 
b = Rata-rata jumlah Daphnia sp. dari ulangan perhitungan

$$
\begin{aligned}
& p=\text { volume media kultur }(L) \\
& q=\text { volume botol sampel }(L)
\end{aligned}
$$

\section{b) Penghitungan}

Biomass

Daphnia sp .

Dalam menghitung biomass Daphnia sp dilakukan dengan menggunakan rumus menurut Izzah et al. (2014) sebagai berikut:

$$
W=\frac{W t-W o}{L}
$$

Keterangan:

$$
\begin{aligned}
& \mathrm{W}=\text { Biomass }(\mathrm{mg} / \mathrm{L}) \\
& \text { W0 = Biomass saat tebar (hari } \\
& \text { ke-0) (mg) } \\
& \mathrm{Wt}=\text { Biomass saat hari ke-n } \\
& \text { (mg) } \\
& \mathrm{L}=\quad=\text { Volume air }(\mathrm{L})
\end{aligned}
$$
diukur dalam kegiatan internship ini antara lain yaitu:

- Suhu: pengukuran, suhu dilaksanakan setiap 4 hari sekali menggunakan termometer digital dan raksa.
- $\mathrm{pH}$, pengukuran $\mathrm{pH}$ dilakukan setiap 4 hari sekali menggunakan $\mathrm{pH}$ meter digital

- Oksigen terlarut, pengukuran oksigen terlarut dilaksanakan setiap 4 hari sekali bersamaan dengan sampling dengan menggunakan DO meter digital.

\section{Analisis Data}

Analisis data menggunakan analisis deskriptif berupa matriks, bar chart, line chart, dan analisis akar permasalahan dilakukan dengan menggunakan rootcause analysis berupa fishbone analysis (Phillips and Simmonds 2013) untuk mengidentifikasi permasalahan yang terjadi dalam kegiatan budidaya Daphnia.

\section{HASIL DAN PEMBAHASAN HASIL}

Pengukuran Parameter Kualitas Air Budidaya Daphnia sp

Paramater kualitas air yang diukur antara lain $\mathrm{pH}$, suhu, dan DO. Pengukuran kualitas air dilakukan pada setiap 4 hari sekali untuk $\mathrm{pH}$ dan suhu sedangkan untuk DO dilakukan pada hari ke-7 dan ke-15. Pengukuran dilakukan di 3 lokasi dengan data hasil pengukuran kualitas air adalah sebagai berikut.

Tabel 2. Hasil pengukuran parameter kualitas air di 3 (tiga) Lokasi.

\begin{tabular}{cccc}
\hline Pembudidaya & Suhu $\left({ }^{\circ} \mathrm{C}\right)$ & $\mathrm{pH}$ & Oksigen Terlarut $(\mathrm{mg} / \mathrm{L})$ \\
\hline Mina B Agribisnis (Unit A) & $24-25$ & $7,3-8,1$ & $2,8-4,5$ \\
\hline \hline
\end{tabular}


Kajian Teknis Budidaya Pakan Alami Daphnia

sp di Unit Hatchery dan Mina B Agribisnis Kota Bogor Provinsi Jawa Barat

$\begin{array}{llll}\text { Kolam Petak Hatchery (Unit } & 24,9-26,4 & 7,2-8,2 & 3,5-4,9 \\ \begin{array}{l}\text { B) } \\ \text { Kolam Bulat Hatchery (Unit }\end{array} & 25,4-25,7 & 6,7-7,6 & 1,1-2,2 \\ \text { C) } & & & \end{array}$

Sumber: Data Primer (2021)

Jumlah Populasi Daphnia sp

pengukuran setiap 4 hari sekali.

Berdasarkan hasil pengukuran

(Zahidah, W. Gunawan 2012).

sampling populasi yang dilakukan di

Berikut dibawah dapat dilihat grafik

3 (tiga) lokasi dengan selang waktu

jumlah populasi dari kolam kelompok.

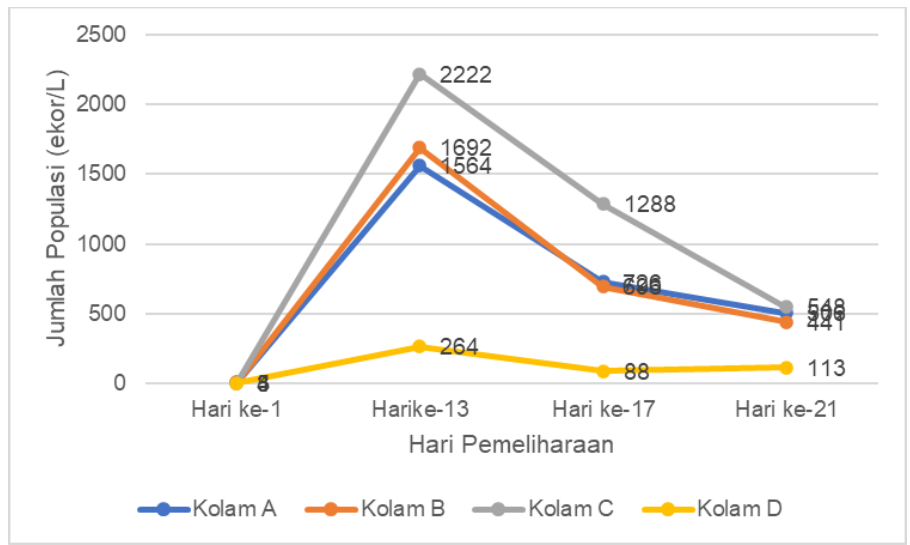

Gambar 1. Grafik Populasi Daphnia sp di Kelompok Mina B Agribisnis

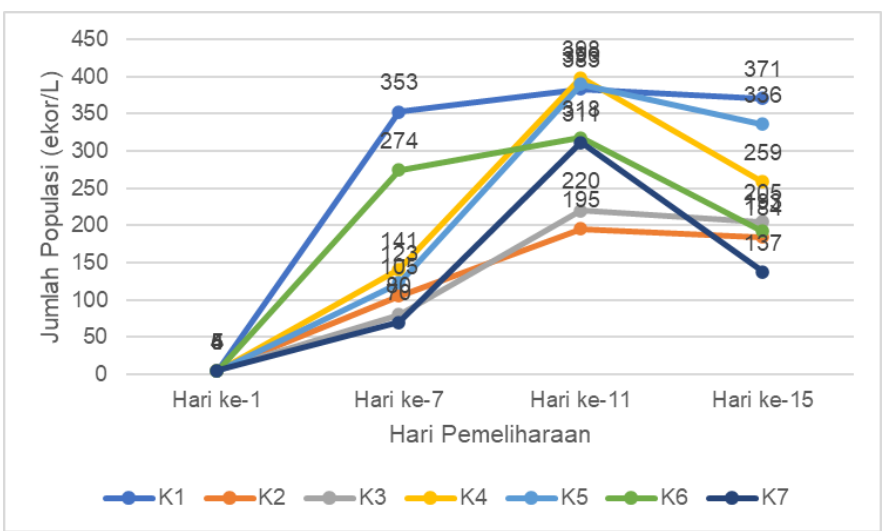

Gambar 2. Grafik Populasi Daphnia sp di unit B 


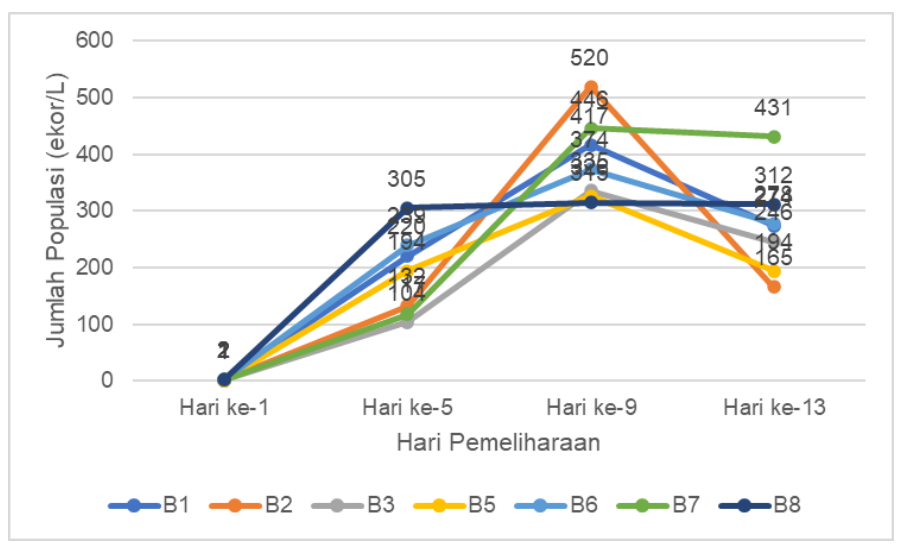

Gambar 3. Grafik Populasi Daphnia sp di unit C

Pada kolam kelompok Mina B Agribisnis (Unit A) hasil sampling jumlah populasi Daphnia sp pada hari ke-13 memperlihatkan jumlah yang tinggi dari setiap kolam Kolam $A$ (1.564 ekor/L), Kolam B (1.692 ekor/L), Kolam C (2.222 ekor/L) dan Kolam D (264 ekor/L) dengan ratarata populasi yaitu 1.436 ekor/L (Gambar 1) dengan rata-rata jumlah populasi sebanyak 1.436 ekor/L apabila dibandingkan pada saat tebar yang hanya 4000 ekor. Untuk unit $C$ Hatchery (bulat B1-B8), hasil sampling jumlah populasi Daphnia sp pada hari ke-9 pada kolam bulat ratarata 390 ekor/L (Gambar 2) dan ke11 pada unit B (petak K1-K7) ratarata 317 ekor/L (Gambar 3) memperlihatkan jumlah populasi tertinggi bila dibandingkan dengan yang lainnya. Bila dilihat dari tren populasi pertumbuhan Daphnia $s p$ ketiga unit tersebut menunjukan pola pergerakan yang sama. Tingkat populasi Daphnia sp dari setiap kolam membentuk kurva sigmoid dengan tahapan dari lag phase, tingkat pertumbuhan spesifik, puncak populasi dan fase kematian.

\section{Jumlah Biomass Daphnia sp}

Produksi biomass Daphnia sp yang dihasilkan dari ke-3 unit kolam dengan rata-rata biomass masingmasing antara lain $1.529 \mathrm{mg} / \mathrm{L}$ untuk unit $A, 337 \mathrm{mg} / L$ untuk unit $B$, dan $416 \mathrm{mg} / \mathrm{L}$ untuk unit C. Grafik biomass Daphnia sp yang dihasilkan dari setiap kolam per kegiatan sampling dapat dilihat pada grafik Gambar 4, Gambar 5 dan Gambar 6. 
Kajian Teknis Budidaya Pakan Alami Daphnia

sp di Unit Hatchery dan Mina B Agribisnis Kota Bogor Provinsi Jawa Barat

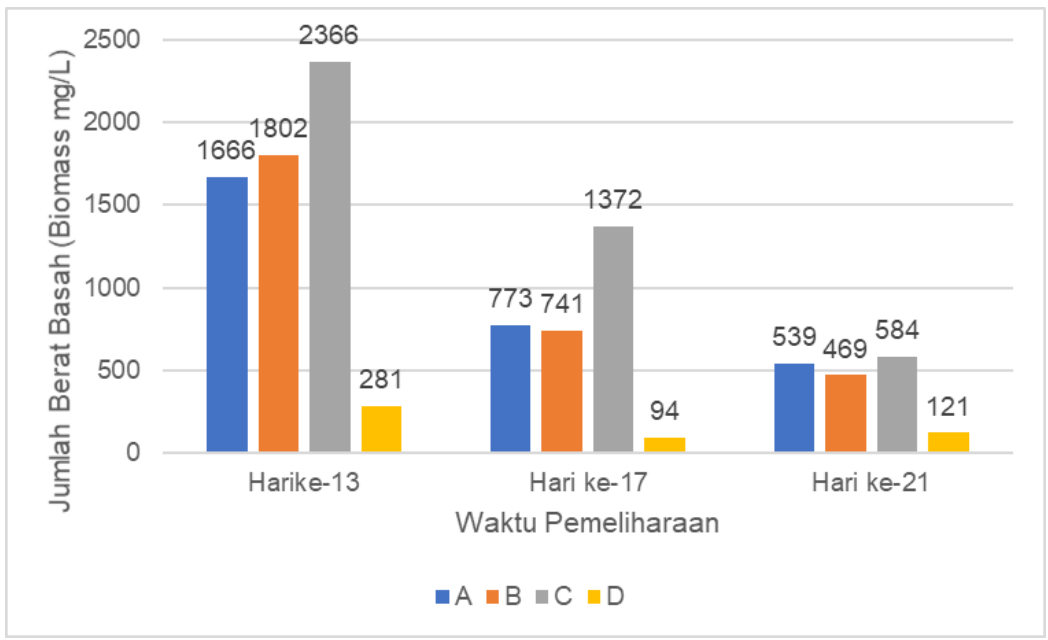

Gambar 4. Grafik Biomass Daphnia sp pada Unit A

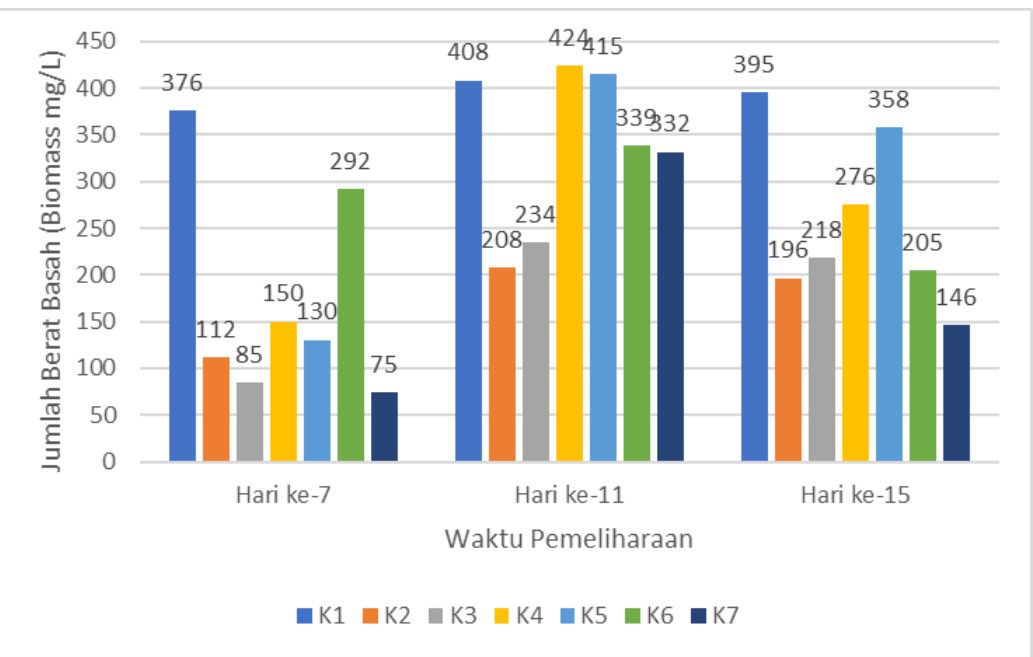

Gambar 5. Grafik Biomass Daphnia sp pada Kolam Unit B

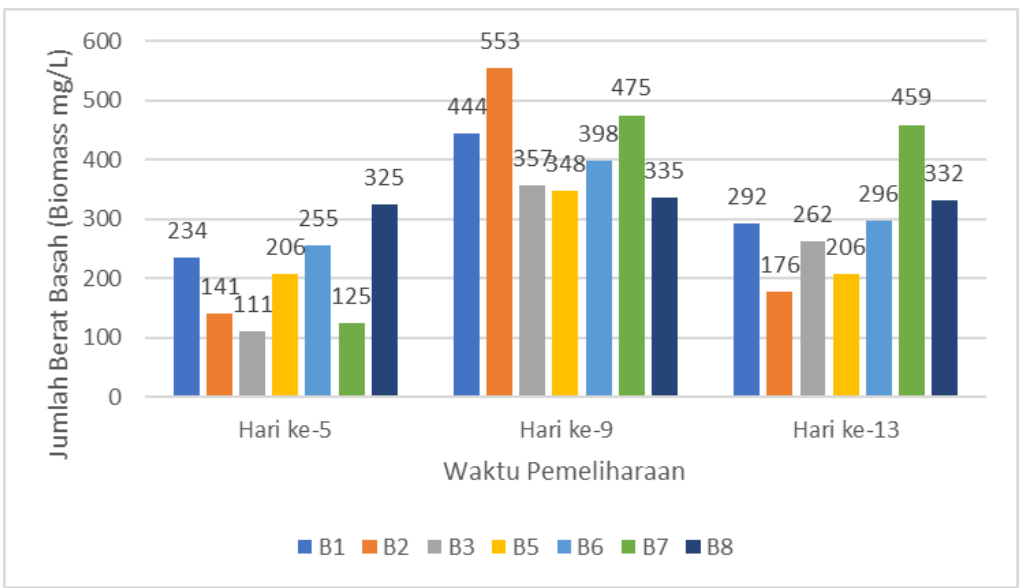

Gambar 6. Grafik Biomass Daphnia sp pada Unit C

Berdasarkan hasil kajian yang telah dilakukan berikut data kondisi dan 
penerapan teknologi disetiap lokasi

pada tabel 3 dibawah ini.

Tabel 3. Data kondisi dan penerapan teknologi di setiap lokasi.

\begin{tabular}{|c|c|c|c|c|c|}
\hline No & Komponen & $\begin{array}{l}\text { Mina B } \\
\text { Agribisnis } \\
\text { (Unit A) }\end{array}$ & $\begin{array}{c}\text { Hatchery } 1 \\
\text { (Unit B) }\end{array}$ & $\begin{array}{c}\text { Hatchery } 2 \\
\text { (Unit C) }\end{array}$ & $\begin{array}{c}\text { Literatur } \\
\text { (El-Feky and } \\
\text { Abo-Taleb } \\
\text { 2020) }\end{array}$ \\
\hline 1. & $\begin{array}{l}\text { Jumlah } \\
\text { penebaran awal } \\
\text { (ekor) }\end{array}$ & 4.500 & 2.000 & 2.000 & 6.210 \\
\hline 2. & $\begin{array}{l}\text { Jenis pakan } \\
\text { yang digunakan }\end{array}$ & $\begin{array}{l}\text { Kotoran } \\
\text { puyuh }\end{array}$ & $\begin{array}{l}\text { Sekam padi } \\
\text { kasar }\end{array}$ & $\begin{array}{l}\text { Sekam padi } \\
\text { kasar }\end{array}$ & Dedak padi \\
\hline 3. & $\begin{array}{l}\text { Jumlah pakan } \\
\text { yang diberikan } \\
\text { (g) }\end{array}$ & $50 \mathrm{~g} /$ hari & $500 \mathrm{~g}$ & $500 \mathrm{~g}$ & $\begin{array}{l}\% \text { pakan : jml } \\
\text { populasi }\end{array}$ \\
\hline 4. & $\begin{array}{l}\text { Cara Pemberian } \\
\text { pakan }\end{array}$ & $\begin{array}{l}\text { Pemberian } 1 \\
\text { kali sehari } \\
\text { dengan cara } \\
\text { dicampur air. }\end{array}$ & $\begin{array}{l}\text { Diikat } \\
\text { memakai } \\
\text { kain halus } \\
\text { dan disimpan } \\
\text { dalam wadah }\end{array}$ & $\begin{array}{l}\text { Diikat } \\
\text { memakai } \\
\text { kain halus } \\
\text { dan disimpan } \\
\text { dalam wadah }\end{array}$ & 2 kali sehari \\
\hline 5. & Volume air (L) & $810-1.280$ & $400-470$ & $960-1.790$ & 90 \\
\hline 6. & $\begin{array}{l}\text { Luas Wadah } \\
\left(\mathrm{m}^{2}\right)\end{array}$ & 6,33 & 1,7 & 2,83 & $\begin{array}{l}\text { Kapasitas } \\
99 \mathrm{~L}\end{array}$ \\
\hline 7. & $\begin{array}{l}\text { Bentuk dan } \\
\text { bahan }\end{array}$ & Terpal bulat & Terpal petak & Terpal bulat & Akuarium \\
\hline 8. & $\begin{array}{l}\text { Kisaran kualitas } \\
\text { air: } \\
\text { Suhu }\left({ }^{\circ} \mathrm{C}\right) \\
\text { DO }(\mathrm{mg} / \mathrm{L}) \\
\text { pH }\end{array}$ & $\begin{array}{l}24-25 \\
2,8-4,5 \\
7,3-8,1\end{array}$ & $\begin{array}{l}24,9-26,4 \\
3,5-4,9 \\
7,2-8,2\end{array}$ & $\begin{array}{l}25,4-25,7 \\
1,1-2,2 \\
6,7-7,6\end{array}$ & $\begin{array}{l}22 \\
5,5 \\
7,8\end{array}$ \\
\hline 9. & $\begin{array}{l}\text { Penggunaan } \\
\text { Aerasi }\end{array}$ & Tidak & Tidak & Tidak & Ada \\
\hline 10. & Penggantian air & Tidak & Tidak & Tidak & $25 \% /$ minggu \\
\hline 11. & Lokasi Kolam & Outdoor & Outdoor & Indoor & indoor \\
\hline 12. & $\begin{array}{l}\text { Perlakuan } \\
\text { lainnya }\end{array}$ & Tidak & Tidak & Tidak & $\begin{array}{l}\text { Penerangan } \\
5000 \text { LUX }\end{array}$ \\
\hline
\end{tabular}

\section{PEMBAHASAN}

\section{Indikator Kinerja Produksi} Budidaya Daphnia sp

Dalam kegiatan budidaya Daphnia sp yang diterapkan salah satu komponen yang perlu diperhatikan yaitu pengelolaan kualitas air. Air merupakan media hidup suatu biota perairan dalam hal ini yaitu Daphnia sp. Salah paramater kualitas air yaitu oksigen terlarut (DO) yang mana oksigen ini digunakan Daphnia sp khususnya untuk respirasi dengan kandungan optimal yang dibutuhkan untuk Daphnia sp yaitu diatas $3.5 \mathrm{mg} / \mathrm{L}$ (Rakhman, Hamdani, and Setiadharma 2012). 
Sedangkan, menurut Kühn et al. (1989). Daphnia sp dapat hidup pada tingkat kandungan oksigen terlarut diatas $1 \mathrm{mg} / \mathrm{L}$.

Rata-rata jumlah populasi yang dihasilkan dari ketiga unit produksi tersebut masih belum mendapatkan hasil yang optimal. Populasi Daphnia sp mampu memcapai lebih dari 10.000 ekor/L (El-Feky and AboTaleb 2020). Ketiga unit produksi tersebut baru mencapai $3,9 \%$ $14,4 \%$.

Rata-rata biomass Daphnia sp yang dihasilkan didasarkan pada waktu puncak populasi yaitu suatu kondisi pertumbuhan populasi tertinggi sebelum mengalami fase kematian. Untuk Kolam di Mina B Agribisnis mengalami fase kematian dalam umur pemeliharaan hari 13 17. Kolam petak (K1-K7) mengalami penurunan populasi pada umur pemeliharaan hari 11 menuju hari ke 15. Begitu pula dengan kolam bulat hatchery penurunan populasi terjadi pada hari 9 menuju hari 13.

Kolam Mina B Agribisnis menghasilkan biomass tertinggi yaitu rata-rata $1.529 \mathrm{mg} / \mathrm{L}$ sedangkan di kolam hatchery menghasilkan sebanyak $337 \mathrm{mg} / \mathrm{L}$ untuk kolam petak dan $416 \mathrm{mg} / \mathrm{L}$ untuk kolam bulat. Sedangkan, menurut El-Feky dan Abo-Taleb (2020) mampu menghasilkan 490 mg/L/minggu dengan fase puncak populasi mencapai $>30$ hari dengan jumlah populasi > 10.000 ind/L. Selain itu, pemberian dedak yang difermentasi ragi (Sitohang, Herawati, and Lili 2012) memberikan pertumbuhan populasi dan biomass yang terbaik. Hal ini menunjukan bahwa pemeliharaan yang didukung dengan teknologi yang sesuai mampu menghasilkan jumlah populasi yang tinggi.

Dilihat dari komponen tingkat konversi pakan yang didapatkan bahwa Mina B Agribisnis dan kolam bulat indoor hatchery mampu menekan tingkat konversi pakan hingga 0,6 dan 0,9. Sedangkan, tingkat konversi pakan untuk kolam petak hatchery masih tinggi yaitu sebesar 3,4. Ketersediaan jumlah pakan yang dibutuhkan untuk proses perkembangbiakan Daphnia sp salah satunya tergantung pada ketersediaan nutrisi pada media pemeliharaan. Selain jumlah pakan yang diberikan, jenis pakan yang diberikan memberikan pengaruh terhadap peningkatan populasi Daphnia sp. Penggunaan pakan yang berasal dari dedak padi mampu menghasilkan jumlah populasi tertinggi dibandingkan dengan tepung jagung, tepung kedelai, dedak gandum, dan tepung alga (El Feky dan Abo Taleb, 2020). Sejalan dengan Herawati et al. (2018) yang melaksanakan kajian tentang 
budidaya Daphnia sp yang menggunakan berbagai jenis nutrisi dan Sitohang et al. (2012) pengkayaan nutrisi dedak padi dalam budidaya Daphnia sp dan hasil pakan menjadi salah satu faktor yan menentukan tingkat populasi Daphnia sp.

\section{Akar Permasalahan}

Berdasarkan data-data diatas, diperoleh hasil rendahnya jumlah populasi Daphnia sp yang dihasilkan dari proses pemeliharaan yang dilakukan baik oleh Kelompok Mina B Agribisnis maupun Unit Hatchery yaitu hanya mampu mencapai 3,9\% - 14,4\% dari produksi optimal. Hal tersebut diakibatkan dari beberapa faktor/komponen tertentu yang belum optimal dilakukan antara lain nutrisi pakan, dan kualitas air (ElFeky dan Abo Taleb 2020; Kühn et al. 1989; Rakhman et al. 2012).

Identifikasi masalah yang terjadi berdasarkan faktor penyebab tersebut disajikan dalam fishbone analysis sebagai berikut:

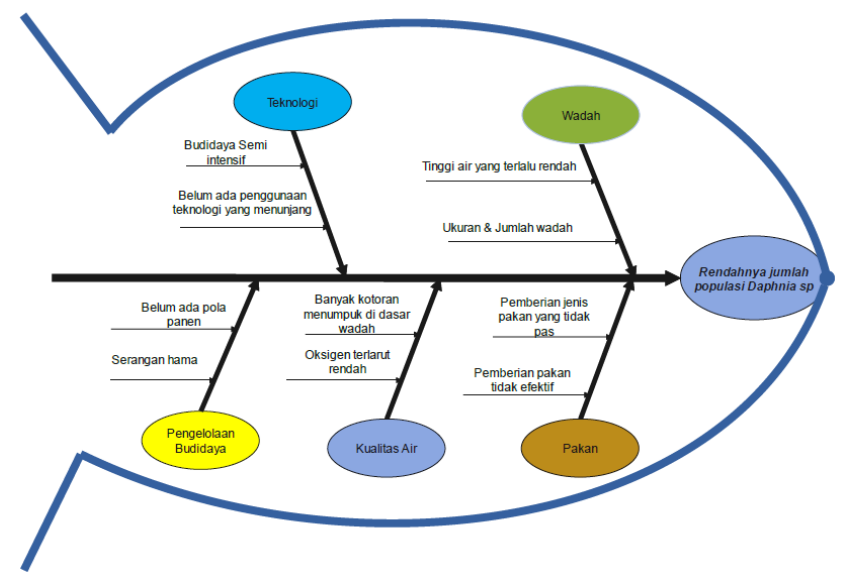

Gambar 4. Fishbone Analysis

rendahnya jumlah populasi Daphnia

$$
\mathrm{sp}
$$

Dengan melihat fishbone analysis diatas maka dapat dikelompokan beberapa faktor yang berpengaruh langsung maupun tidak langsung terhadap jumlah populasi Daphnia sp. Identifikasi faktor sebab akibat terhadap permasasalahan yang ada dapat dilihat pada tabel dibawah ini.

Tabel 4. Identifikasi sebab-akibat masalah

\begin{tabular}{|c|c|c|c|c|}
\hline No & Faktor & Sebab & akibat & $\begin{array}{l}\text { Langsung/Tidak } \\
\text { Langsung }\end{array}$ \\
\hline 1 & Wadah & $\begin{array}{l}\text { Ukuran wadah dan } \\
\text { rendahnya ketinggian } \\
\text { air yang digunakan }\end{array}$ & $\begin{array}{l}\text { Tingkat persaingan } \\
\text { yang tinggi }\end{array}$ & Tidak langsung \\
\hline
\end{tabular}




\begin{tabular}{|c|c|c|c|c|}
\hline 2 & Pakan & $\begin{array}{l}\text { Jenis pakan yang } \\
\text { kurang baik }\end{array}$ & $\begin{array}{l}\text { Ketersediaan nutrisi } \\
\text { untuk Daphnia sp hidup, } \\
\text { tumbuh } \\
\text { bereproduksi }\end{array}$ & Langsung \\
\hline 3 & Pakan & $\begin{array}{l}\text { Cara pemberian } \\
\text { pakan tidak efektif }\end{array}$ & $\begin{array}{l}\text { Ketersediaan nutrisi dan } \\
\text { tingkat persaingan } \\
\text { makanan }\end{array}$ & Langsung \\
\hline 3 & Air & DO rendah & Tidak ada aerasi & Tidak langsung \\
\hline 4 & Air & $\begin{array}{l}\text { Kotoran menumpuk } \\
\text { di dasar }\end{array}$ & Perubahan kualitas air & Tidak langsung \\
\hline 5 & $\begin{array}{l}\text { Pengelolaan } \\
\text { Budidaya }\end{array}$ & $\begin{array}{l}\text { Serangan hama } \\
\text { (Larva capung) dan } \\
\text { kompetitor (Paku air) }\end{array}$ & $\begin{array}{l}\text { Penurunan } \\
\text { populasi }\end{array}$ & Langsung \\
\hline 6 & $\begin{array}{l}\text { Pengelolaan } \\
\text { Budidaya }\end{array}$ & $\begin{array}{l}\text { Belum ada pola } \\
\text { panen }\end{array}$ & $\begin{array}{l}\text { Tingginya tingkat } \\
\text { persaingan } \\
\text { mengakibatkan } \\
\text { penurunan populasi } \\
\text { Daphniasp }\end{array}$ & Tidak Langsung \\
\hline 7 & Teknologi & $\begin{array}{l}\text { Belum ada } \\
\text { pengunaan teknologi } \\
\text { yang diterapkan } \\
\text { untuk meningkatkan } \\
\text { produksi }\end{array}$ & $\begin{array}{l}\text { populasi tidak optimal } \\
\text { sesuai dengan kondisi } \\
\text { wadah }\end{array}$ & Tidak langsung \\
\hline
\end{tabular}

\section{Rekomendasi Pemecahan Masalah}

Berdasarkan identifikasi

permasalahan maka dapat dilakukan

identifikasi intervensi atau solusi pemecahan masalah yang dapat dilaksanakan baik dilakukan secara segera atau diperlukan kajian dan pertimbangan lainnya sebagai berikut:

Tabel 5. Identifikasi Intervensi pemecahan masalah

\begin{tabular}{|c|c|c|c|}
\hline No & Usulan Intervensi & Prioritas & Keterangan \\
\hline 1 & Ketinggian air diatas $\pm 40 \mathrm{~cm}$ & $\begin{array}{l}\text { Mendesak } \\
\text { Penting }\end{array}$ & - Dilakukan Segera \\
\hline 2 & $\begin{array}{l}\text { Dedak padi padi menjadi alternatif jenis } \\
\text { pakan yang dberikan (El-Feky and } \\
\text { Abo-Taleb 2020; Sitohang et al. 2012) }\end{array}$ & $\begin{array}{l}\text { Tidak mendesak } \\
\text { Penting }\end{array}$ & $\begin{array}{l}\text { - Dilakukan jika } \\
\text { memungkinkan }\end{array}$ \\
\hline 3 & $\begin{array}{l}\text { Pakan alternatif lain yang } \\
\text { memungkinkan sebagai pakan } \\
\text { pengganti speerti bungkil kelapa dan } \\
\text { bekatul (Izzah et al. 2014) }\end{array}$ & $\begin{array}{l}\text { Tidak mendesak } \\
\text { Penting }\end{array}$ & $\begin{array}{l}\text { - Perlu } \\
\text { Pertimbangan } \\
\text { dan kajian }\end{array}$ \\
\hline 4 & $\begin{array}{l}\text { Penggunaan bahan supplemen dan } \\
\text { atau addiktif pada pakan yang akan } \\
\text { diberikan seperti fermentasi dan } \\
\text { lainnya (Islama et al. 2020; Izzah et al. } \\
\text { 2014; Noviantoro, A. Sudaryono, A dan } \\
\text { Nugroho 2017) }\end{array}$ & $\begin{array}{l}\text { Tidak mendesak } \\
\text { Penting }\end{array}$ & $\begin{array}{l}\text { - Perlu } \\
\text { Pertimbangan } \\
\text { dan kajian }\end{array}$ \\
\hline 5 & $\begin{array}{l}\text { Pemberian pakan dilakukan } 1-2 \\
\text { kali/hari dengan cara dihaluskan dan }\end{array}$ & $\begin{array}{l}\text { Mendesak } \\
\text { Penting }\end{array}$ & - Dilakukan Segera \\
\hline
\end{tabular}


diencerkan terlebih dahulu. (El-Feky and Abo-Taleb 2020)

6 Ditambahkan aerator pada wadah Mendesak budidaya terutama untuk wadah yang didalam ruangan untuk meningkatkan

- Dilakukan jika tingkat oksigen terlarut (Samhari, Hasan, and Raharjo 2014)

7 Penyiponan dasar wadah secara teratur setiap minggu, Pembersihan hama dan tanaman paku air

8 Penerapan biosecurity sederhana

Tidak mendesak - Dilakukan jika Penting memungkinkan

9 Menerapkan Pola Panen

Tidak mendesak - Perlu Penting Pertimbangan dan kajian 
Kajian Teknis Budidaya Pakan Alami Daphnia

sp di Unit Hatchery dan Mina B Agribisnis Kota Bogor Provinsi Jawa Barat

Rekomendasi untuk dapat meningkatkan produktivitas dalam budidaya Daphnia sp dibagi menjadi jangka pendek dan jangka panjang. Rekomendasi jangka pendek dapat dilakukan langsung atau sesegera mungkin atau pun dilakukan saat dimungkinkan. Sedangkan, rekomendasi jangka panjang diperlukan pertimbangan dan kajian lebih lanjut. Adapun rekomendasi yang dihasilkan antara lain:

1) Jangka pendek

- Ketinggian air dalam wadah pemeliharaan $\geq 40 \mathrm{~cm}$;

- Pemberian pakan dilakukan sebanyak 1-2 kali/hari dengan cara dihaluskan terlebih dahulu;

- Penggunaan aerator pada setiap wadah;

- Penyiponan dasar wadah untuk membuang kotoran yang berada di dasar kolam;

- Pembersihan tanaman paku air apabila keberadaannya telah menutupi perairan dalam wadah.

2) Jangka Menengah

- Penggunaan pakan alternatif/pakan dari sumber lainnya;

- Penggunaan bahan supplemen dan atau addiktif pada pakan yang akan diberikan untuk meningkatkan nutrisi pakan yang diberikan;
- Menerapkan pola panen dalam kegiatan budidaya Daphnia sp untuk meningkatkan produktivitas.

\section{SIMPULAN DAN SARAN}

Berdasarkan hasil yang didapatkan dari kajian Budidaya Daphnia sp yang dilakukan di kelompok Mina B Agribisnis dan Hatchery Unit Komunikasi dan Penyuluhan Bogor antara lain sebagai berikut:

1) Metode budidaya Daphnia sp yang diterapkan di kelompok Mina B Agribisnis dan Hatchery Unit Komunikasi dan Penyuluhan Bogor masih menggunakan budidaya semi intensif dengan penerapan teknologi pengelolaan pakan dan pengeloaan kualitas air yang belum efektif.;

2) Rendahnya jumlah populasi yang dihasilkan baru mencapai $3,9 \%-14,4 \%$ dari produksi optimal.

3) Penerapan teknologi dalam meningkatkan jumlah produksi Daphnia dapat menerapkan perlakuan pada rekomendasi jangka pendek.

Saran yang dapat diberikan antara lain untuk meningkatkan jumlah produksi Daphnia sp dapat menerapkan hasil rekomendasirekomendasi jangka pendek 
sedangkan untuk rekomendasi jangka menengah dapat dijadikan suatu topik penelitian/kajian lain untuk meningkatkan produktivitas dalam kegiatan Budidaya Daphnia sp.

\section{PERSANTUNAN}

Penulis mengucapkan terima kasih Kelompok Mina B Agribisnis dan Unit Praktek Lapang, Komunikasi dan Penyuluhan Kampus yang telah mengijinkan Penulis melakukan kajian pada lokasi tersebut.

\section{DAFTAR PUSTAKA}

Akbar, M. Galdio Novalli, Herman Hamdani, and Ibnu Dwi Buwono. 2017. "Pengaruh Perbedaan Pupuk Organik Terhadap Laju Kematian Populasi Daphnia Sp." Jurnal Perikanan Dan Kelautan 2017(2):176-82.

Ebert, D. 2005. "Chapter 2 Introduction to Daphnia Biology." Ecology, Epidemiology, and Parasitism in Daphnia [Internet] (Md):1-25.

El-Feky, Mohamed M. M., and Hamdy Abo-Taleb. 2020. "Effect of Feeding with Different Types of Nutrients on Intensive Culture of the Water Flea, Daphnia Magna Straus, 1820." Egyptian Journal of Aquatic Biology and Fisheries 24(1):655-66. doi:
10.21608/EJABF.2020.76554.

Herawati, Vivi Endar, Pinandoyo, Johannes Hutabarat, and Ocky Karnaradjasa. 2018. "The Effect of Nutrient Content and Production of Daphnia Magna Mass Cultured Using Various Wastes Processed with Different Fermentation Time." $A A C L$ Bioflux 11(4):1289-99.

Islama, Dini, Nurhatijah Nurhatijah, Muhammad Muntadhar, and Muhammad Fadhli. 2020. "Pengaruh Pemberian Sumber Nutrien Berbeda Pada Media Kultur Terhadap Kepadatan Populasi Dan Laju Pertumbuhan Daphnia Sp." Jurnal Akuakultura 2(2). doi: 10.35308/ja.v2i2.1591. Izzah, Nailul, Suminto, and Vivi Endar Herawati. 2014. "Pengaruh Pemberian Sumber Nutrien Berbeda Pada Media Kultur Terhadap Kepadatan Populasi Dan Laju Pertumbuhan Daphnia Sp." Journal of Aquaculture Management and Technology.

Kühn, Renate, Monika Pattard, Klaus Dieter Pernak, and Angela Winter. 1989. "Results of the Harmful Effects of Water Pollutants to Daphnia Magna in the 21 Day Reproduction Test." Water Research. doi: 10.1016/0043-1354(89)90142-

5.

Luthfi, Haris, Nawir Muhar, and Mas 
Kajian Teknis Budidaya Pakan Alami Daphnia

sp di Unit Hatchery dan Mina B Agribisnis Kota Bogor Provinsi Jawa Barat

Eriza. 2014. "Pengaruh

Pemberian Fermentasi Dedak

Dan Ragi Roti Terhadap

Pertumbuhan Populasi Daphnia

Magna."

Noviantoro, A. Sudaryono, A dan

Nugroho, R. A. 2017. "Produksi

Daphnia Sp. Yang

Dibudidayakan Dengan

Kombinasi Ampas Tahu Dan

Berbagai Kotoran Hewan Dalam

Pupuk Berbasis Roti Afkir Yang

Difermentasi." Journal of

Aquaculture Management and

Technology 4(4):95-100.

Pangkey, Hanneke. 2009. "Daphnia

Sp. Dan Penggunaannya."

Jurnal Perikanan Dan Kelautan

5(2):33-36.

Phillips, Joanna, and Lorraine

Simmonds. 2013. "Using

Fishbone Analysis to Investigate

Problems." Nursing Times 109(15).

Rakhman, Eri, Herman Hamdani, and

Gunawan Setiadharma. 2012.

"Pengaruh Urine Kelinci Hamil

Dalam Media Kultur Terhadap

Kontribusi Anak Setiap

Kelompok Umur Daphnia Spp."

Jurnal Perikanan Dan Kelautan

Unpad.

Samhari, Rosa, Hastiadi Hasan, and

Eka Indah Raharjo. 2014.

"Pengaruh Pemberian Kalsit

Dengan Kadar Yang Berbeda
Terhadap Perkembangan

Populasi Daphnia Sp." Jurnal

Ruaya 4.

Sison-Mangus, Marilou P., Alexandra

A. Mushegian, and Dieter Ebert. 2015. "Water Fleas Require Microbiota for Survival, Growth and Reproduction." ISME Journal. doi: 10.1038/ismej.2014.116.

Sitohang, Richardson V, Titin Herawati, and Walim Lili. 2012. "Effect of Giving Rice Bran Yeast Fermentation (Saccharomyces Cerevisiae) on the Growth of Biomass Daphnia Sp." Jurnal Perikanan Kelautan 3(1):65-72.

Surtikanti, Hertien Koosbandiah, Rahardian Juansah, and Diah Frisda. 2017. "Optimalisasi Kultur Daphnia Yang Berperan Sebagai Hewan Uji Dalam Ekotoksikologi." Jurnal Biodjati 2(2):83. doi:

10.15575/biodjati.v2i2.1571.

Zahidah, W. Gunawan, dan U. Subhan. 2012. "Pertumbuhan Populasi Daphnia Spp. Yang Diberi Pupuk Limbah Budidaya Karamba Jaring Apung (KJA) Di Waduk Cirata Yang Telah Difermentasi EM4." Jurnal Akuatika III(1):84-94. 